\title{
Language Learning Strategy-Task Corollary: A Case of Jigsaw vs. Problem-solving Tasks
}

\author{
Gholam-Reza Abbasian, RezvanShojaei
}

Imam Ali \& Islamic Azad (South Tehran Branch) Universities, Faculty of Persian Literature\& Foreign Languages (IAU, South Tehran), Palestine Sq., Tehran, IR IRAN; Postal Code: 1416894351 gabbasian@gmail.com

Islamic Azad University (Science\& Research Branch), Faculty of Foreign Languages\& Literature, KabirZadeh Blvd., South Janat Abad, Tehran, IR IRAN; Postal Code: 1474694943

$$
\text { r_shojaei80@yahoo.com }
$$

\begin{abstract}
This study aimed at investigating the relationship between language learning strategy use and performing jigsaw and problem-solving tasks. For this purpose, 53 students of a total 77 BA students majoring at ELT, English Literature, and English Translation were chosen through taking the Standardized Nelson English Proficiency Test. The homogeneous participants were randomly divided into two experimental groups: jigsaw and problem-solving. The jigsaw group practiced reading comprehension through jigsaw tasks while the problem-solving group did so through problem-solving tasks. Strategic behavior of each group was assessed through administrating the Strategy Inventory of Language Learning (SILL) prior to and after the treatment. The dataobtained undergone three main statistical analyses: independent sample ttest, paired samples t-test and MANOVA. Between group comparison indicated that the two groups were not much different regarding the strategy use implying that task type does not much affect strategy use. However, within group comparisons revealed that, although thestrategies as a unitary entity did not change as a result of the exposure to the task types, they showed changes in their use of various components of the strategies; metacognitive, social, and cognitive strategies were used most frequently by the members of both groups. Interestingly, the findings sustain the old but still attractive notion of Gestalt Psychology that 'the whole, is other than sum of the parts' (Kurt Koffka)'.
\end{abstract}

\section{Key words}

Language learning strategies; Strategy use; Jigsaw tasks; Problem-solving tasks

\section{Academic Discipline and Sub-Disciplines}

Applied Linguistics/ Language Teaching

Subject Classification

Task-based Teaching

Type (Method/Approach)

Experimental

\section{Council for Innovative Research}

Peer Review Research Publishing System

\section{Journal: Journal of Social Sciences Research}

Vol. 6, No. 2

Jssreditor.cir@gmail.com

www.jssronline.com 


\section{INTRODUCTION}

Due to the growing interest in language learning, language scholars have been attempting to find ways which can promote language learning. For many years the focus was on teaching methods and classroom techniques; however, in the late sixties, it became increasingly clear that improvement in teaching methods required a more direct understanding of the language learning process (Naiman,1978), which consists of both unconscious mental processes and consciously employed strategies as "steps taken by students to enhance their own learning" (Oxford, 1990, p.1). Moreover, learning strategies , according to her (1990, p.8) "are specific actions taken by learners to make learning easier, faster, more enjoyable, more self-directed, more effective, and more transferable to new situations".

Different classifications for (language) learning strategies (LLSs) have been proposed. According to Hsiao and Oxford (2002), Oxford's taxonomyis the most consistent with learners' strategy use.Oxford (1990) classified strategies as direct and indirect strategies. Direct strategies are those which directly involve the target language, subdivided into memory, cognitive, and compensation strategies. Indirect strategies do not directly involve using the language, but they support language learning. They are further divided into metacognitive, affective, and social strategies (Oxford, 1990).

Theoretically and empirically, strategy use and input processing, the latter one as the core of learning, are interwoven in cognitive theories. Anderson's information processing model approaches to second language learning consider learning as transition from declarative to procedural knowledge, which according to Mitchel and Myles (1998) happens through utilizing language learning strategies. In their view, language learning strategies are complex procedures that individuals apply to tasks; consequently, they may be represented as procedural knowledge which may be acquired through cognitive, associative, and autonomous stages of learning. "As with other procedural skills at the different stages of learning, the strategies may be conscious at the early stages and later be performed without the person's awareness" (O'Malley \&Chamot, 1990, p.52). On the contrary, sociocultural and sociolinguistic theorists emphasize the social nature of interaction (Mitchel\& Myles, 1998). They report that for Vygotsky skilled individuals are capable of autonomous functioning or self-regulation, as the central concept to his theory. According to Berk and Winsler (1995, cited in Oxford, 1999), selfregulation is the process of planning, guiding, and monitoring one's own attention and behavior which are known as metacognitive learning strategies. Oxford (1999) maintains that social interaction requires strategies such as asking questions, requesting assistance, and collaborating with others using language which are called social strategies. Affective, compensatory, and memory strategies are also believed by Oxford (1999) to be part of learner's self-regulation. So, learning strategies, though not explicitly stated, is an integrative part to Vygotsky's theory. Nevertheless, choice of language learning strategies, according to Oxford (1989), is subject to many variables including: language being learned, duration, degree of awareness, age, sex, affective variables such as motivation and attitude, personality characteristics, general personality type, learning style, aptitude, career orientation, national origin, language teaching methods, and task requirements. These factors have been touched upon in numerous researchesin relation to, e.g., level of proficiency (Ehrman and Oxford, 1988; Oxford and Ehrman, 1995; Dreyer and Oxford, 1996; Hong- Nam and Leavell, 2006), motivation (Oxford and Nyikos, 1989; Oxford and Ehrman, 1995; Taguchi, 2002; Ziahosseeini and Salehi, 2008), gender (Oxford and Nyikos, 1989; Oxford and Ehrman, 1995; Dreyer and Oxford, 1996; Bacon, 1992). Junsheng (2008) compared learners' strategy use in virtual and actual situations and found that strategy use depends on the nature of the task. Kaivanpanah, Yamouty and Karami (2012), who explored use of communication strategies in doing different task types, concluded that task type had a significant impact on the type of communication strategies employed.

Among many factors, task type has received much attention in second language instruction and in the era of strategic teaching. Task is defined by Ellis $(2003, p .16)$ as "a work plan that requires learners to process language pragmatically in order to achieve an outcome......, it requires them to give primary attention to meaning and to make use of their own linguistic resources. A task is intended to result in language use that bears a resemblance, direct or indirect, to the language used in real world". Contribution of task to language skill acquisition and strategy use has been subject to various empirical research studies. For example, Oxford et al. (2004) examined reading strategies of 36 adult ESL learners in relation to incorporation of task and proficiency level. The results showed that there was no significant main effect in aggregated strategy use across tasks or between proficiency levels, which were also supported by Sotudenam and Azimfar's (2011) as well as Fazilatfar's (2010) studies.Khan (2010) conducted a study on the strategies used in performing three oral communication tasks, a picture story, an art description, and an information gap. Comparing the three tasks in terms of aggregated strategy use indicated that the participants had used the most number of strategies while doing the information-gap task. It was concluded that the higher strategy use on the information gap task was due to comparatively greater use of interactional and compensation strategies by the group.

Junsheng (2008) explored the interaction integration of senior secondary students' language learning strategies, styles and tasks in a school in Fujian, China. The evidence revealed that when the students were provided with virtual tasks in the questionnaire, cognitive strategies were those that were predominantly used. By contrast, when they elaborated on their strategic actions undertaken to perform actual tasks, cognitive and metacognitive strategies are seen to be vital in their learning. In brief, the students' strategy use depends on the nature of the tasks. When learning tasks shift from virtual tasks to actual tasks, the students' strategy use relies increasingly on the ongoing regulatory process.

Use of learning strategies has been considered to be one of the crucial factors for successful language learning. The early studies of language learning strategies such as those by Rubin (1975), Stern (1975) and Naiman (1978) have alleged that good language learners are strategic ones. Rubin (1975) states that good language learners involve themselves actively in all aspects of language learning such as affective, linguistic, and environmental ones. However, their learning behavior might be subject to certain variables including the nature of the task (Oxford, 1990). Surprisingly, Nunan (1998) maintains that there are a number of language learning strategies underlying every task. These indicate some sort of link between tasks and language learning strategies.According to Ellis (2003)tasks are activities which are intended to result in language use that resembles the way language is used in real world. He states that tasks develop L2 proficiency through interaction as they include some kind of gap in information, opinion, or reasoning which stimulates the learners to use language in order to close the gap. Swain (1995, as cited in Beglar\& Hunt, 2002) points out tasks provide learners with 
input as well as the opportunity for meaningful use of language. It is believed that learners' cognitive processing will be engaged by this combination of contextualized input and output helping learners to process and reshape the input. Therefore, tasks are considered as valuable activities which promote language teaching (Ellis, 2003).

Similar to LLSs, tasks have also been classified differently depending on their nature in input processing. Pedagogically speaking, Richards (2001, p.162) suggests two broad categories of tasks including pedagogical and real world tasks. The former types "are based on second language acquisition theories and are designed to trigger second language learning processes and strategies. Real world tasks are designed to practice those activities that are found to be important in a needs analysis and that turn out to be important and useful in real life". In the same vein, Prabhu (1987) considers three types of pedagogical tasks: information-gap, reasoning-gap, and opinion-gap tasks. According to Willis (1996), there are six types of tasks: listing, ordering and sorting, comparing, problem-solving, sharing personal experiences, and creative tasks.

Richards (2001) considers five task types: jigsaw, information-gap, problem-solving, decision-making, and opinionexchange tasks. Richards' classification seems to be more tangible pedagogically. However, two of them;jigsawand problem solving tasks are probably the most commonly used ones. The former, sometimes called split-information task (Willis\&Willis, 2007), is an activity in which groups or individuals are expected to combine individual pieces of information, thereby they are involved in communication and collaborative work (Willis \&Willis, 2007; Richards, 2001). In the latter category, however, learners are given a problem and a set of information. They have to communicate with each other in order to find a solution (Richards, 2001). Willis (1996) believes problem-solving tasks are challenging, engaging, and satisfying to solve. They require people's intellectual and reasoning power.

Pica et al. (1993, as cited in Smith, 2003) rank the task types based on their effect on second language learning: (1) jigsaw; (2) information-gap; (3) problem solving; (4) decision making; and (5) opinion exchange. Accordingly, jigsaw and problem solving tasks are considered as facilitative tasks for second language learning. Doughty and Pica (1986) compared a required information exchange task (jigsaw task) and an optional information exchange task in terms of the amount of modified interaction generated.Results indicated that more modification of interaction happened in doing the jigsaw task than did in doing the optional information exchange task. The researchers emphasized that a required information exchange task is necessary for the generation of conversational modifications of classroom interaction. Swain and Lapkin (2000) compared a jigsaw task and a dictogloss task in terms of the amount of focus on form. It was indicated that the students focused equally on form while doing both task types. What's more, the jigsaw task seemed to inspire greater linguistic creativity as the students used a greater range of vocabulary and language related episodes. Mengdus and Xialing (2010) used jigsaw technique to teach reading to a group of college students. They discovered that jigsaw technique is an effective way to promote students' participation and interest as well as a good technique to accomplish learning tasks in the EFL classroom.Kazemi (2012) compared the effect of traditional ways of teaching reading and using jigsaw to do so on students' reading comprehension achievement. The results indicated that jigsaw technique has a significant effect on students' reading achievement as the students' reading comprehension improved as a result of practicing jigsaw reading. Fredricks (1984) used a problem-solving task, a role play, and an authentic interaction in order to compare the language generated by the three tasks. The results showed that while doing the problem-solving task the students generated more communicative functions of language but narrower range of form and lexis. Poupore (2005) explored quality interaction and types of negotiation in problem- solving and jigsaw tasks. Based on the results of the study, Poupore considers problem- solving prediction tasks as being more beneficial than jigsaw tasks. He argues that the more open structure of the problem- solving tasks gives the learner more freedom to use a wider variety of language. Hussein et.al (2012) used a problem-solving approach to teach writing to a group of EFL students. The topic which was in form of a problem was discussed within group and even between groups before writing. Results indicated that the students writing improved in terms of content, grammar, and organization of ideas.

Addressing tasks empirically is rationalized both theoretically and pedagogically. Oxford et al. (2004) hold that including a task in second language learning strategy assessment is necessary because in this case learners will focus on the strategies they use to do the particular task. Cohen and Macaro (2007) emphasize the need for assessing the strategic behavior of the learners in the context of specific tasks. However, there seems to be a dearth of research in this particular area.Moreover, research on language learning strategies has mainly focused on the strategies of good language learner, strategy instruction, and factors affecting language learning strategy use. Among these factors, task requirements contrary to some sporadic studies, has still received little attention. Additionaly, probing learners' language learning strategy use in practicing reading comprehension through incorporating tasks in general and the jigsaw and problemsolving tasks in particular is wararnted. Sinceas the literature reviewed confirms, jigsaw and problem-solving tasks are valuable task types as they have required qualities for language leaning. They are both motivating and involve a great deal of negotiation of meaning. Therefore, using them in language classes will contribute to the students' progress in language learning; a claim requires more empirical supports. Rationalized in this way, this study tries to investigate the role of task types (jigsaw and problem solving) in LLS choice both individually and comparatively in a reading instruction class, which was realized in the following research questions addressed in the form of respective null hypotheses.

\section{RESEARCH QUESTIONS}

1. Does task type (jigsaw vs. problem- solving)have any statistically distinct effect on language learning strategy use both unitarily and componentially?

2. Does exposure to jigsaw tasks have any statistically distinct effect on language learning strategy use both unitarily and componentially?

3. Does exposure to problem-solving tasks have any statistically distinct effect on language learning strategy use both unitarily and componentially?

Note: the research questions were addressed as respective null hypotheses. 


\section{RESEARCH METHOD}

\subsection{Participants}

Participants of the current study were 53 male and female students from Azad and ShahidBahonar universities of Kerman, Iran, majoring in English Literature, ELT, and English Translation. The mean age of the participants was 21, ranging from 18 to 36, who were selected through the Standardized Nelson English Proficiency Test (Version 300D) out of total population of 77 students. The students whose score fell within the range of one SD \pm mean were selected as the participants of the study.

\subsection{Instrumentation}

The instruments used in this study were the Standardized Nelson English Proficiency Test, the Strategy Inventory for Language Learning(SILL) (Oxford,1990), and jigsaw and problem-solving tasks. The Standardized Nelson English Proficiency Test which was used to choose a homogeneous group of participantsconsists of 50 items including reading, grammar, vocabulary, and pronunciation items. The Strategy Inventory for Language Learningconsists of six categories: memory strategies (9 items), cognitive strategies (14 items), compensation strategies (6 items), metacognitive strategies (9items), affective strategies (6 items), and social strategies (6 items). These SILL 50 items are evaluated on a five-point Likert scale from 1 to 5 . The tasks employedwere jigsaw and problem-solving reading comprehension tasks. The problemsolving tasks were developed based on suggestions made by Willis (1996) in the form of giving advice to other people, predicting the end of a story, or choosing the best course of action to do something. In order to make sure that the texts used by both groups enjoyed the same level of difficulty, the readability of the texts was estimated usingGunnig-Fog formula.

\subsection{Procedure}

To collect the required data, a group of homogeneous participants was divided into two groups which differed in terms of the treatment they received. One group practiced reading comprehension through jigsaw tasks and the other through problem-solving tasks. In order to elicit the strategic behavior of the participants, the SILL was administered twice, before and after treatment.

\section{DATA ANALYSIS}

\subsection{Reliability and Validity of SIIL and Nelson Test}

Regardless of the already proven nature of the instruments in terms of reliability and validity, both of them were subjected to further validation process based on principal component analysis (i.e., varimaxrotation), indicating five factor loadings as the validity indices (Table 1) and KR-21 statistical formula showing the reliability ratios (Table 2).

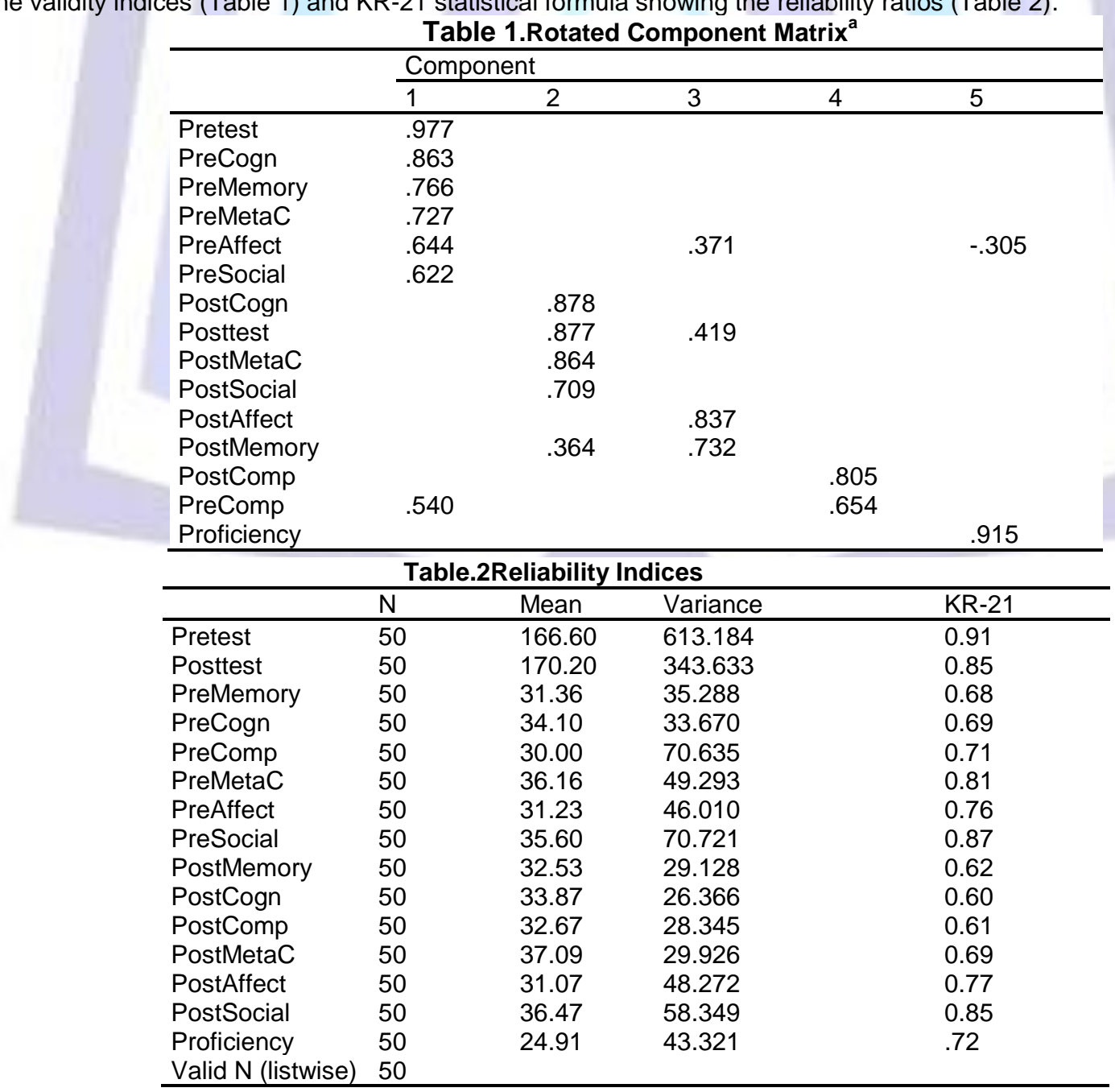




\subsection{Results}

\subsubsection{Homogeneity Measures}

Table 3 displays the descriptive statistics of the participants selected for the study:

Table.3 Descriptive Statistics

\begin{tabular}{|c|c|c|c|c|}
\hline & & class1 & class 2 & class 3 \\
\hline \multirow[t]{2}{*}{$\mathrm{N}$} & Valid & 15 & 20 & 18 \\
\hline & Missing & 38 & 33 & 35 \\
\hline $\mathrm{Me}$ & & 24.0000 & 24.2500 & 24.2778 \\
\hline & of Mean & .81064 & .87622 & .73122 \\
\hline & & 23.0000 & 24.5000 & 24.5000 \\
\hline Mo & & 22.00 & $25.00^{\mathrm{a}}$ & 20.00 \\
\hline & tion & 3.13961 & 3.91858 & 3.10229 \\
\hline & & 9.857 & 15.355 & 9.624 \\
\hline & & 12.00 & 13.00 & 9.00 \\
\hline & & 20.00 & 18.00 & 20.00 \\
\hline & & 32.00 & 31.00 & 29.00 \\
\hline
\end{tabular}

Table.4 Tests of Normality

\begin{tabular}{|l|l|l|l|l|l|l|}
\hline \multicolumn{4}{|l}{} & \multicolumn{5}{l|}{ Kolmogorov-Smirnov ${ }^{\text {a }}$} & Shapiro-Wilk \\
\cline { 2 - 7 } & Statistic & df & Sig. & Statistic & df & Sig. \\
\hline class1 & 225 & 15 & .050 & .889 & 15 & .074 \\
class 2 & 145 & 15 & $.200^{*}$ & .934 & 15 & .311 \\
class 3 & 134 & 15 & $.200^{*}$ & .920 & 15 & .193 \\
\hline
\end{tabular}

a. Lilliefors Significance Correction

*This is a lower bound of the true significance.

Based on the level of significance displayed in table 4, the distribution of the scores is normal.

Table.5 Test of Homogeneity of Variances of Scores

\begin{tabular}{|l|l|l|l|}
\hline Levene Statistic & df1 & df2 & Sig. \\
\hline 1.025 & 2 & 50 & .366 \\
\hline
\end{tabular}

As sig $=0.366>0.05$ the variance of the scores in the three classes are the same.

\subsubsection{Testing Normality Assumptions}

The data collected in this study enjoyed normal distributions. As displayed in table 6 the values of skewdness and kurtosis were lower than their critical values (c.r.).

\section{Table.6 Assessment of Normality; Components of Language Learning Strategies}

\begin{tabular}{|l|llllll|}
\hline Variable & $\min$ & $\max$ & Skew & c.r. & kurtosis & c.r. \\
\hline Pre. Memory & 18.889 & 45.556 & .135 & .389 & -.122 & -.175 \\
Pre. Cognition & 15.714 & 47.143 & -.723 & -2.087 & 1.368 & 1.974 \\
Pre. Compensation & 13.333 & 50.000 & -.025 & -.072 & -.362 & -.523 \\
Pre. Metacognitive & 17.778 & 50.000 & -.455 & -1.312 & -.187 & -.271 \\
Pre. Affective & 18.333 & 45.000 & .120 & .347 & -.719 & -1.037 \\
Pre. Social & 16.667 & 50.000 & -.361 & -1.042 & -.280 & -.403 \\
Post. Memory & 22.222 & 44.444 & .143 & .412 & -.110 & -.159 \\
Post. Cognitive & 21.429 & 43.571 & -.497 & -1.436 & .059 & .085 \\
Post. Compensation & 20.000 & 45.000 & -.197 & -.567 & -.116 & -.167 \\
Post. Metacognitive & 23.333 & 48.889 & -.136 & -.392 & .023 & .034 \\
Post. Affective & 11.667 & 46.667 & -.072 & -.209 & .145 & .209 \\
Post. Social & 18.333 & 48.333 & -.320 & -.924 & -.695 & -1.003 \\
\hline
\end{tabular}

Besides, the components of the total pretest and posttest enjoyed normal distributions (Table 7), since they lie between $\pm 1.96$

Table.7 Assessment of Normality; Pretest and Posttest of Language Learning Strategies

\begin{tabular}{|l|llllll|}
\hline Variable & $\min$ & $\max$ & skew & c.r. & kurtosis & c.r. \\
\hline Posttest & 127.000 & 207.000 & -.370 & -1.067 & .161 & .233 \\
Pretest & 93.000 & 218.000 & -.258 & -.744 & .600 & .866 \\
\hline
\end{tabular}




\subsubsection{Investigation of the First Research Question}

The first research question addressing the task types (jigsaw vs. problem-solving) to find out if it has any statistically distinct effect on language learning strategy( LLS) types, was probed twice for investigating the effect of two different treatments on language learning strategies as a unitary construct first and then on its components.

\subsubsection{Learning strategies as a unitary construct}

An independent t-test was run to compare jigsaw and problem-solving groups on the posttest of LLS. As displayed in table 8 , the jigsaw group $(\mathrm{M}=171.42, \mathrm{SE}=3.81)$ showed a slightly higher mean score than the problem-solving group did ( $\mathrm{M}=$ $169.08, \mathrm{SD}=3.66$ ) on posttest of language learning strategies (LLS).

Table.8 LLS in Posttest

\begin{tabular}{ccccc}
\hline Group & $\mathrm{N}$ & Mean & Std. Deviation Std. Error Mean \\
\hline Jigsaw & 24 & 171.42 & 18.696 & 3.816 \\
Problem-Solving 26 & 169.08 & 18.687 & 3.665 \\
\hline
\end{tabular}

The results of the independent $\mathrm{t}$-test $(\mathrm{t}(48)=.44, \mathrm{P}>.05, \mathrm{R}=.064$ representing a weak effect size) (Table.9) indicated that there was not any significant difference between the two groups' mean scores on the posttest of the LLS. The nullhypothesis was not rejected.

Table.9 Independent T-test of Posttest LLS Used by Groups

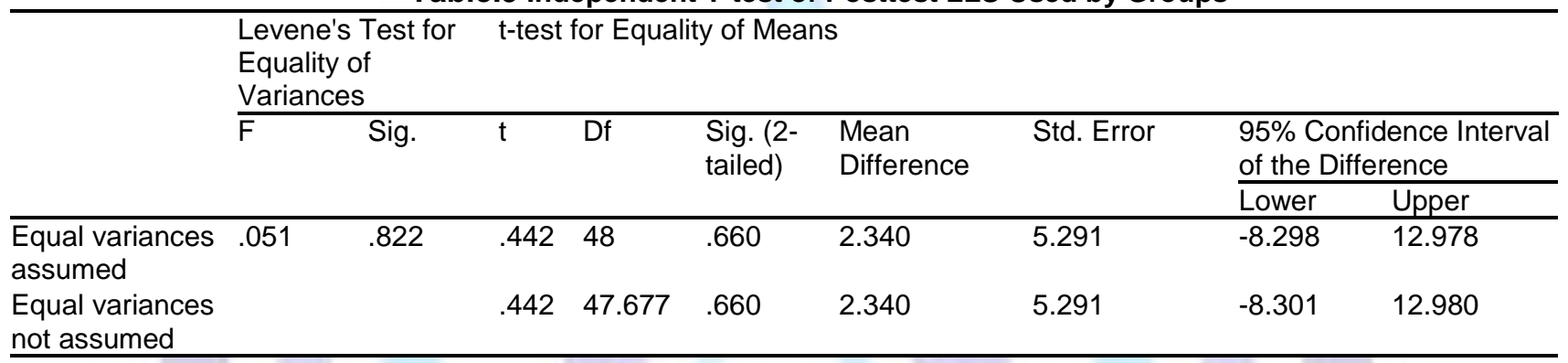

It should be noted that the assumption of homogeneity of variances was met (Levene's $F=.051, P>.05$ ). That is why the first row of table 9, i.e. "Equal variances not assumed" was reported.

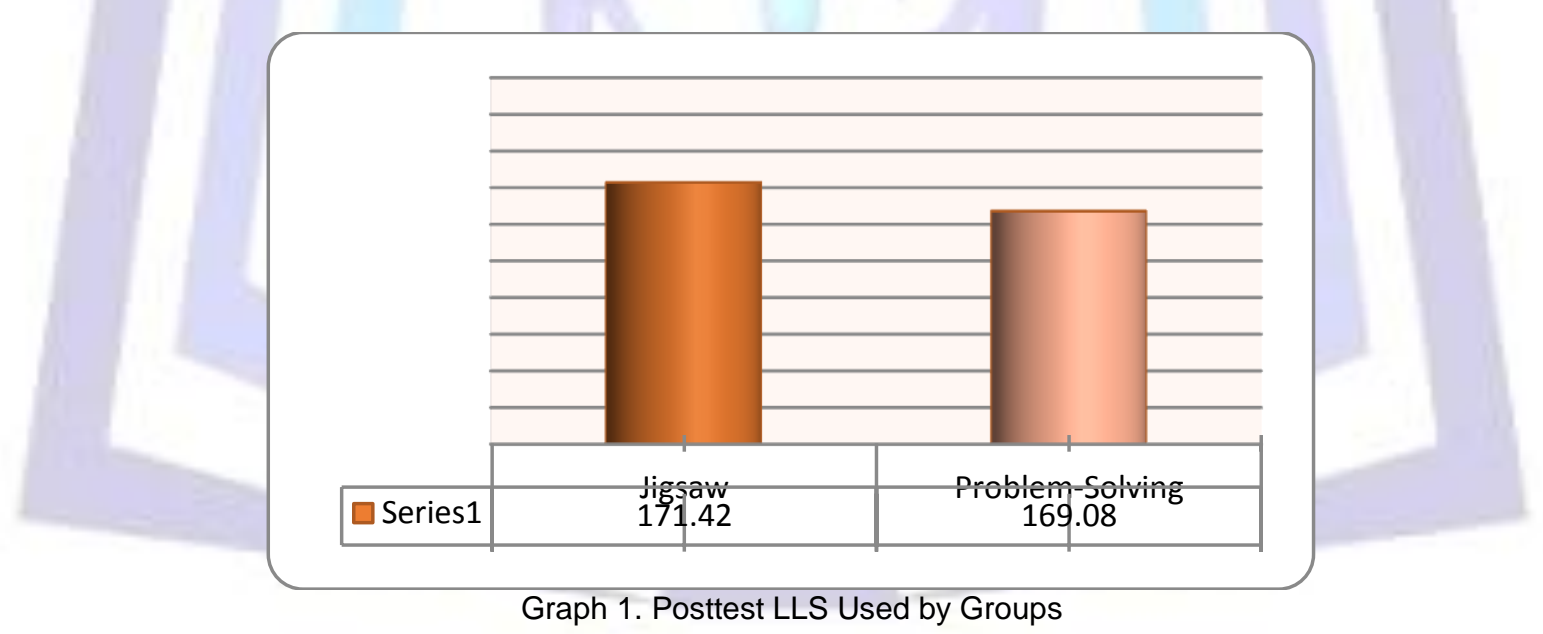

\subsubsection{Components of LLSs}

A multivariate ANOVA (MANOVA) was run to investigate the effect of jigsaw and problem-solving methods on the components of LLS. Before reporting the main results, it should be noted that the assumption of homogeneity of variances - as tested through the Levene's F-values - and the assumption of homogeneity of covariance - as tested through the Box's test - were met. As displayed in table 10, the probabilities associated with the Levene's F-values were all higher than .05. Thus, the assumption of homogeneity of variances was met.

Table 10.Levene's Test of Equality of Error Variances

\begin{tabular}{lllll}
\hline & $\mathrm{F}$ & $\mathrm{df1}$ & $\mathrm{df2}$ & Sig. \\
\hline Post. Memory & .099 & 1 & 48 & .755 \\
Post. Cognition & .054 & 1 & 48 & .818 \\
Post. Compensation & .089 & 1 & 48 & .767 \\
Post. Metacognitive & .005 & 1 & 48 & .943 \\
Post. Affective & .364 & 1 & 48 & .549 \\
Post. Social & 2.563 & 1 & 48 & .116 \\
\hline
\end{tabular}


Besides enjoying homogenous variances, the groups enjoyed homogenous covariance matrices as the Box's M-value of 19.91 was not significant $(P>$.05) (Table 11). Thus, the assumption of homogeneity of covariance matrices was also met.

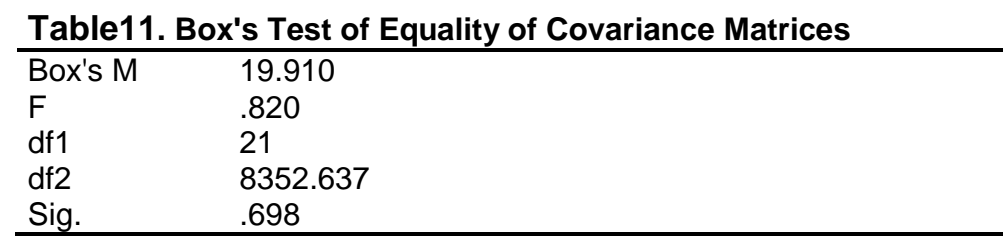

Table12. Tests of Between-Subjects Effects

\begin{tabular}{|c|c|c|c|c|c|c|c|}
\hline Source & Dependent Variable & $\begin{array}{l}\text { Type III Sum of } \\
\text { Squares }\end{array}$ & df & Mean Square & $\mathrm{F}$ & Sig. & $\begin{array}{l}\text { Partial Eta } \\
\text { Squared }\end{array}$ \\
\hline \multirow{7}{*}{ Group } & Post. Memory & 14.918 & 1 & 14.918 & .507 & .480 & .010 \\
\hline & Post. Cognition & 4.875 & 1 & 4.875 & .182 & .672 & .004 \\
\hline & Post. Compensation & 20.513 & 1 & 20.513 & .720 & .401 & .015 \\
\hline & Post. Metacognitive & 28.187 & 1 & 28.187 & .941 & .337 & .019 \\
\hline & Post. Affective & 191.865 & 1 & 191.865 & 4.237 & .045 & .081 \\
\hline & Post. Social & 17.551 & 1 & 17.551 & .296 & .589 & .006 \\
\hline & Post. Memory & 1412.342 & 48 & 29.424 & & & \\
\hline \multirow{5}{*}{ Error } & Post. Cognition & 1287.054 & 48 & 26.814 & & & \\
\hline & Post. Compensation & 1368.376 & 48 & 28.508 & & & \\
\hline & Post. Metacognitive & 1438.208 & 48 & 29.963 & & & \\
\hline & Post. Affective & 2173.469 & 48 & 45.281 & & & \\
\hline & Post. Social & 2841.560 & 48 & 59.199 & & & \\
\hline & Post. Memory & 54348.148 & 50 & & & & \\
\hline \multirow{5}{*}{ Total } & Post. Cognition & 58655.612 & 50 & & & & \\
\hline & Post. Compensation & 54744.444 & 50 & & & & \\
\hline & Post. Metacognitive & 70245.679 & 50 & & & & \\
\hline & Post. Affective & 50622.222 & 50 & & & & \\
\hline & Post. Social & 69350.000 & 50 & & & & \\
\hline
\end{tabular}

The only significant difference observed between jigsaw $(\mathrm{M}=29.02)$ and problem-solving $(\mathrm{M}=32.49)$ groups' means was on posttest of affective strategies $\left(F(1,48)=4.32, P<.05\right.$, Partial $\eta^{2}=.081$, representing a moderate effect size).

Table 13. Descriptive Statistics; Components of LLS

\begin{tabular}{|c|c|c|c|c|c|}
\hline \multirow{2}{*}{$\begin{array}{l}\text { Dependent Variable } \\
\text { Post. Memory }\end{array}$} & Group & Mean & \multicolumn{3}{|c|}{ Std. Error 95\% Confidence Interval } \\
\hline & Jigsaw & 33.102 & 1.107 & 30.876 & 35.328 \\
\hline & Problem-Solving & 32.009 & 1.064 & 29.870 & 34.147 \\
\hline \multirow[t]{2}{*}{ Post. Cognitive } & Jigsaw & 34.196 & 1.057 & 32.071 & 36.322 \\
\hline & Problem-Solving & 33.571 & 1.016 & 31.530 & 35.613 \\
\hline \multirow[t]{2}{*}{ Post. Compensation } & Jigsaw & 33.333 & 1.090 & 31.142 & 35.525 \\
\hline & Problem-Solving & 32.051 & 1.047 & 29.946 & 34.157 \\
\hline \multirow[t]{2}{*}{ Post. Metacognitive } & Jigsaw & 37.870 & 1.117 & 35.624 & 40.117 \\
\hline & Problem-Solving & 36.368 & 1.074 & 34.209 & 38.526 \\
\hline \multirow[t]{2}{*}{ Post. Affective } & Jigsaw & 29.028 & 1.374 & 26.266 & 31.790 \\
\hline & Problem-Solving & 32.949 & 1.320 & 30.295 & 35.602 \\
\hline \multirow[t]{2}{*}{ Post. Social } & Jigsaw & 37.083 & 1.571 & 33.926 & 40.241 \\
\hline & Problem-Solving & 35.897 & 1.509 & 32.864 & 38.931 \\
\hline
\end{tabular}




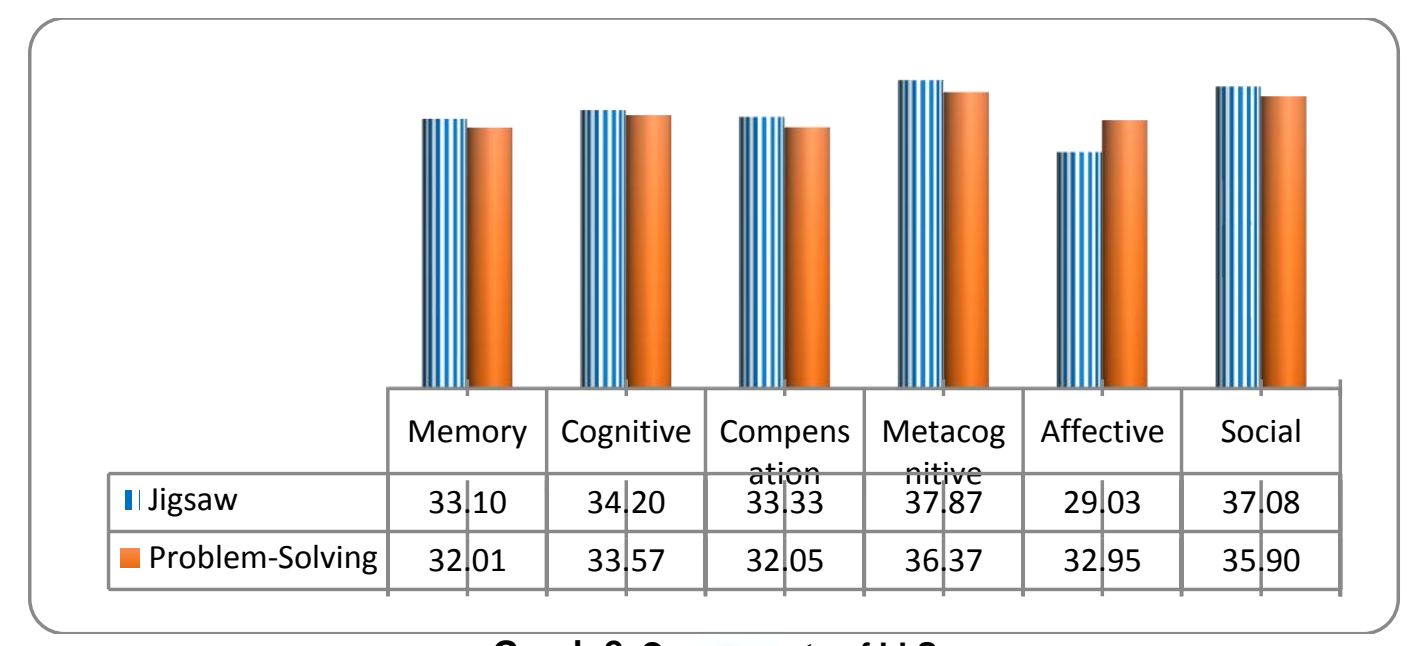

Graph 2. Components of LLS

So, when language learning strategies are treated as discrete construct composed of various sub-strategies, different picture is revealed indicating that in certain areas (i.e. affective strategies), though not in majority of the cases, task type affects the use of language learning strategies.

\subsubsection{Investigation of the Second Research Question}

The second research question, concerned with the effect of exposure to jigsaw tasks on the use of language learning strategies by Iranian EFL learners, was addressed twice probing the effect of jigsaw tasks on language learning strategies as a unitary construct first and then on its components.

\subsubsection{Learning strategies as a unitary construct (jigsaw group)}

A paired-samples t-test was run to compare jigsaw group's means on pretest and posttest of language learning strategies as a unitary construct. As displayed in table 14, the jigsaw group showed a higher mean on the posttest of LLSs (M = $171.42, \mathrm{SE}=3.81)$ than did on the pretest $(\mathrm{M}=163.58, \mathrm{SD}=4.10)$.

Table14.Paired Samples Statistics

\begin{tabular}{lll}
\hline \multicolumn{3}{c}{ Mean N Std. Deviation Std. Error Mean } \\
\hline Posttest 171.42 2418.696 & 3.816 \\
Pretest & 163.582420 .106 & 4.104 \\
\hline
\end{tabular}

The results of the paired-samples t-test $(t(23)=1.64, P>.05, R=.32$ representing a moderate effect size) (table 15) indicated that there was not any statistically significant difference between the jigsaw group's means on the pretest and posttest of language learning strategies indicating that the hypothesis was not rejected. However, there is some moderate degree of difference between the two means.

Table15.Paired-Samples T-test Pretest and Posttest of LLS (Jigsaw Group)

\begin{tabular}{|c|c|c|c|c|c|c|}
\hline \multicolumn{4}{|c|}{ Paired Differences } & \multirow[t]{3}{*}{$-T$} & \multirow[t]{3}{*}{ Df } & \multirow[t]{3}{*}{ Sig. (2-tailed) } \\
\hline Mean & Std. Deviation & Std. Error Mean & $\begin{array}{l}\text { 95\% Confidence Interval of the } \\
\text { Difference }\end{array}$ & & & \\
\hline & & & Lower $\quad$ Upper & & & \\
\hline 7.833 & 23.360 & 4.768 & 17.698 & 1.643 & 23 & .114 \\
\hline
\end{tabular}




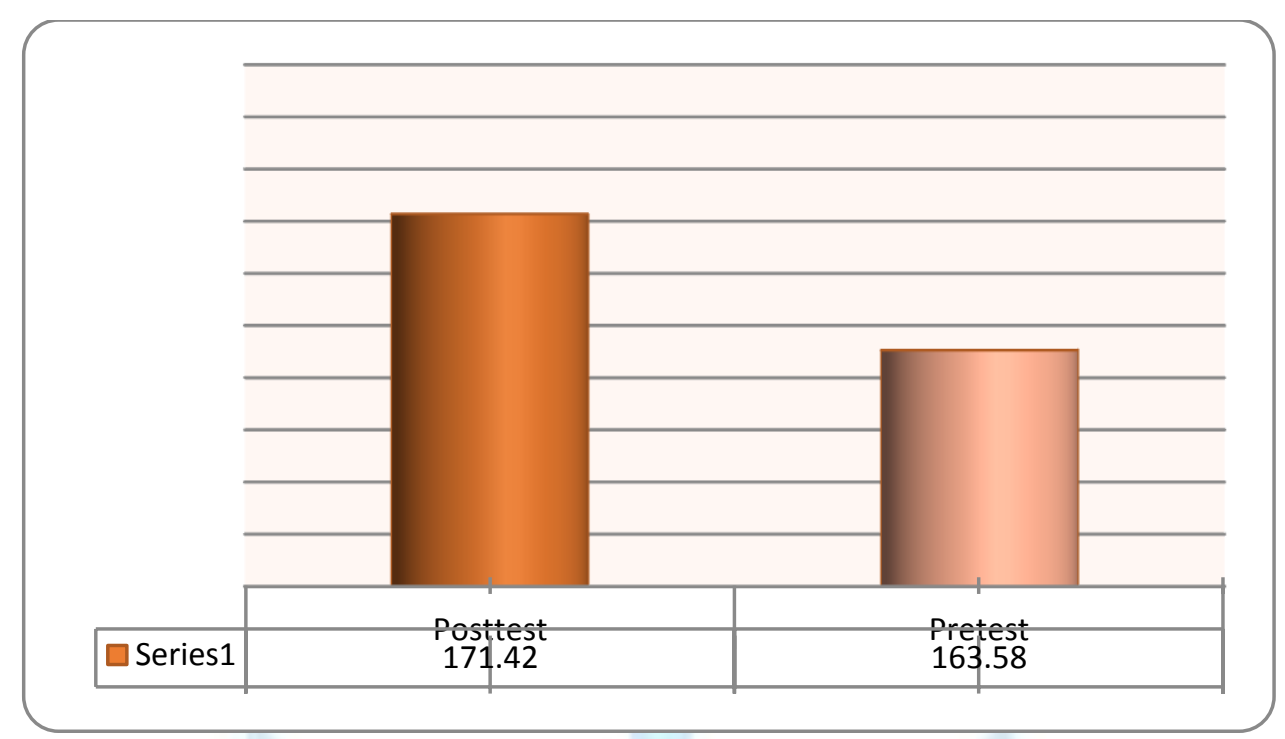

Graph 3.Pretest and Posttest of LLS (Jigsaw Group)

\subsubsection{Components of LLSs}

A repeated measures ANOVA was run to compare jigsaw group's means on pretest and posttest of component of LLS. Based on the results displayed in tables 16 and 17, it can be concluded that there was a significant difference between the jigsaw group's overall means on pretest $(M=32.47)$ and posttest $(M=34.10)\left(F(1,23)=2.87, P>.05, P a r t i a l \eta^{2}=.11\right.$, representing a moderate to large effect size). Although the F-value of 2.87 was not significant, the effect size value of .11 indicated that the jigsaw group had a moderate to large improvement from the pretest to posttest. Then, the nullhypothesis was rejected.

Table16.Multivariate Tests; Pretests and posttests of Components of LLS (Jigsaw Group)

\begin{tabular}{llllll}
\hline Effect & & \multicolumn{3}{c}{ Value F } & \multicolumn{3}{c}{ Hypothesis df Error df Sig. Partial Eta Squared } \\
\hline Strategy & Pillai's Trace & .635 & 6.6175 & 19 & .001 .635 \\
& Wilks' Lambda & .365 & 6.6175 & 19 & .001 .635 \\
& Hotelling's Trace & 1.7416 .6175 & 19 & .001 .635 \\
\multirow{5}{*}{ Time } & Roy's Largest Root & 1.7416 .6175 & 19 & .001 .635 \\
& Pillai's Trace & .111 & 2.8811 & 23 & .103 .111 \\
& Wilks' Lambda & .889 & 2.8811 & 23 & .103 .111 \\
& Hotelling's Trace & .125 & 2.8811 & 23 & .103 .111 \\
\multirow{3}{*}{ Strategy * Time } & Roy's Largest Root & .125 & 2.8811 & 23 & .103 .111 \\
& Pillai's Trace & .430 & 2.8725 & 19 & .043 .430 \\
& Wilks' Lambda & .570 & 2.8725 & 19 & .043 .430 \\
& Hotelling's Trace & .756 & 2.8725 & 19 & .043 .430 \\
& Roy's Largest Root & .756 & 2.8725 & 19 & .043 .430 \\
\hline
\end{tabular}

Table17. Descriptive Statistics; Pretest and posttest of LLS (Jigsaw Group)

\begin{tabular}{lllll}
\hline Time & Mean & Std. Error & \multicolumn{2}{c}{$95 \%$ Confidence Interval } \\
\cline { 3 - 5 } & & & Lower Bound & Upper Bound \\
\hline Pretest & 32.474 & .847 & 30.722 & 34.227 \\
Posttest & 34.102 & .753 & 32.545 & 35.659 \\
\hline
\end{tabular}

Based on the results displayed in tables 18 and 19, it can be concluded that there were significant differences between the jigsaw group's means on the components of LLSs; disregarding the time variable $\left(F(5,19)=6.61, P<.05, P a r t i a l \eta^{2}=\right.$ .63 , representing a large effect size).

As displayed in table 16, the jigsaw group showed the highest means on metacognitive $(M=36.75)$, social $(M=36.35)$ and cognitive $(M=33.88)$. They showed almost the same means on memory $(M=31.75)$, compensation $(M=30.93)$ and affective $(\mathrm{M}=30.03)$. 
Table18.Descriptive Statistics; Components of LLS (Jigsaw Group)

\begin{tabular}{lllll}
\hline Strategy & Mean & Std. Error & \multicolumn{2}{c}{ 95\% Confidence Interval } \\
\cline { 3 - 5 } & & & Lower Bound & Upper Bound \\
\hline Memory & 31.759 & .992 & 29.708 & 33.811 \\
Cognitive & 33.884 & .774 & 32.283 & 35.484 \\
Compensation & 30.938 & 1.237 & 28.378 & 33.497 \\
Metacognitive & 36.759 & .950 & 34.795 & 38.724 \\
Affective & 30.035 & 1.142 & 27.672 & 32.397 \\
Social & 36.354 & 1.364 & 33.532 & 39.177 \\
\hline
\end{tabular}

Table 19 displays the results of the post-hoc comparison tests. Based on these results, it can be concluded that there were significant differences between the following two means;
A: Metacognitive $(M=36.75)$ and Memory $(M=31.75)(M D=5, P<.05)$.
$B$ : Metacognitive $(M=36.75)$ and Compensation $(M=30.93)(M D=5.82, P<.05)$.
C: Metacognitive $(M=36.75)$ and Affective $(M=30.03)(M D=6.72, P<.05)$.
$D$ : Social $(M=36.35)$ and Memory $(M=31.75)(M D=1.59, P<.05)$.
E: Social $(M=36.35)$ and Affective $(M=30.03)(M D=6.31, P<.05)$.
F: Cognitive $(M=33.88)$ and Affective $(M=30.03)(M D=3.84, P<.05$

Table19.Post-Hoc Comparison Tests; Components of LLS (Jigsaw Group)

$\begin{array}{lll}\text { (I) Strategy } & \text { (J) Strategy } & \text { Mean Difference (I-J) Std. Error Sig. } \\ \end{array}$

\begin{tabular}{|c|c|c|c|c|}
\hline \multirow{2}{*}{$\begin{array}{l}\text { (I) Strategy } \\
\text { Memory }\end{array}$} & (J) Strategy & \multicolumn{3}{|c|}{ Mean Difference (I-J) Std. Error Sig. ${ }^{b}$} \\
\hline & Cognitive & -2.125 & 1.014 & .712 \\
\hline & Compensation & .822 & 1.586 & 1.000 \\
\hline & Metacognitive & $-5.000^{x}$ & 1.291 & .012 \\
\hline & Affective & $\overline{1.725}$ & 1.017 & 1.000 \\
\hline & Social & $-4.595^{\star}$ & 1.242 & .018 \\
\hline \multirow[t]{5}{*}{ Cognitive } & $\overline{\text { Memory }}$ & 2.125 & $\overline{1.014}$ & $\overline{.712}$ \\
\hline & Compensation & 2.946 & 1.195 & .324 \\
\hline & Metacognitive & -2.875 & 1.003 & .130 \\
\hline & Affective & $\underline{3.849^{*}}$ & $\underline{1.121}$ & .034 \\
\hline & $\overline{\text { Social }}$ & -2.470 & $\overline{1.071}$ & $\overline{.456}$ \\
\hline \multirow[t]{5}{*}{ Compensation } & Memory & -.822 & 1.586 & 1.000 \\
\hline & Cognitive & -2.946 & 1.195 & .324 \\
\hline & Metacognitive & $-5.822^{*}$ & $\underline{1.733}$ & .041 \\
\hline & $\overline{\text { Affective }}$ & .903 & $\overline{1.760}$ & $\overline{1.000}$ \\
\hline & Social & -5.417 & 1.956 & .163 \\
\hline \multirow[t]{5}{*}{ Metacognitive } & Memory & $\underline{5.000^{*}}$ & 1.291 & .012 \\
\hline & $\overline{\text { Cognitive }}$ & $\overline{2.875}$ & $\overline{1.003}$ &.$\overline{130}$ \\
\hline & Compensation & $5.822^{*}$ & 1.733 & .041 \\
\hline & Affective & $\underline{6.725^{\star}}$ & 1.312 & .001 \\
\hline & Social & .405 & $\overline{1.469}$ & $\overline{1.000}$ \\
\hline \multirow[t]{6}{*}{ Affective } & Memory & -1.725 & 1.017 & 1.000 \\
\hline & Cognitive & $-3.849^{*}$ & 1.121 & .034 \\
\hline & Compensation & -.903 & $\overline{1.760}$ & $\overline{1.000}$ \\
\hline & Metacognitive & $-6.725^{\star}$ & $\underline{1.312}$ & .001 \\
\hline & Social & $-6.319^{\star}$ & $\overline{1.349}$ & .002 \\
\hline & Memory & $4.595^{\star}$ & 1.242 & .018 \\
\hline \multirow{4}{*}{ Social } & $\overline{\text { Cognitive }}$ & $\overline{2.470}$ & $\overline{1.071}$ & .456 \\
\hline & Compensation & 5.417 & 1.956 & .163 \\
\hline & Metacognitive & -.405 & 1.469 & 1.000 \\
\hline & Affective & $6.319^{*}$ & 1.349 & .002 \\
\hline
\end{tabular}

*. The mean difference is significant at the .05 level. (Highlighted, underlined and italicized)

Note. Each comparison was reported twice. The negative sign means that the first mean was smaller.

Based on the results displayed in tables 17 and 20 , it can be concluded that there was significant and large interaction between time and components of language learning strategies $\left(F(5,19)=2.87, P<.05\right.$, Partial $\eta^{2}=.43$, representing a large effect size). Bar Graph 6 displays the jigsaw group's means on components of pretests and posttests of language learning strategies. 
Table 20.Descriptive Statistics; Time*Components (Jigsaw Group)

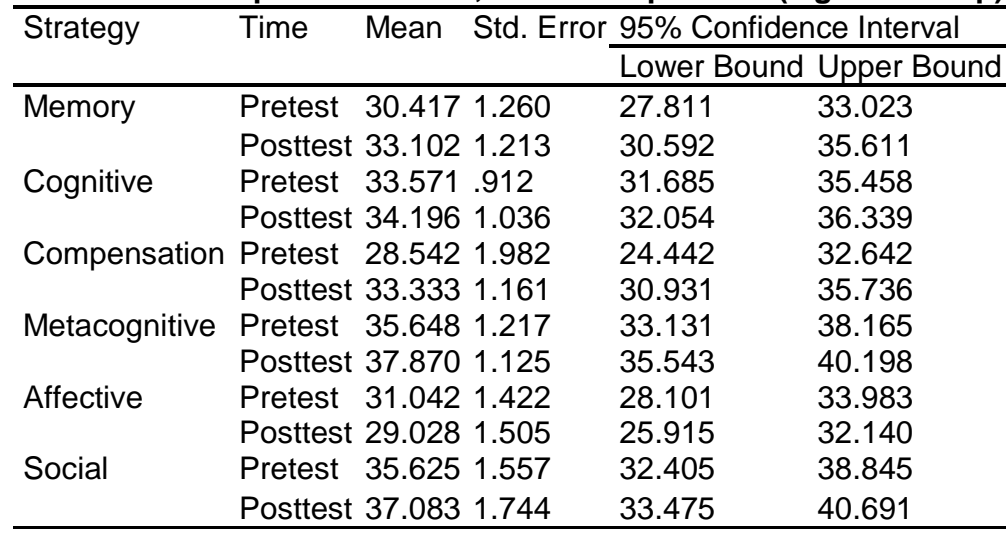

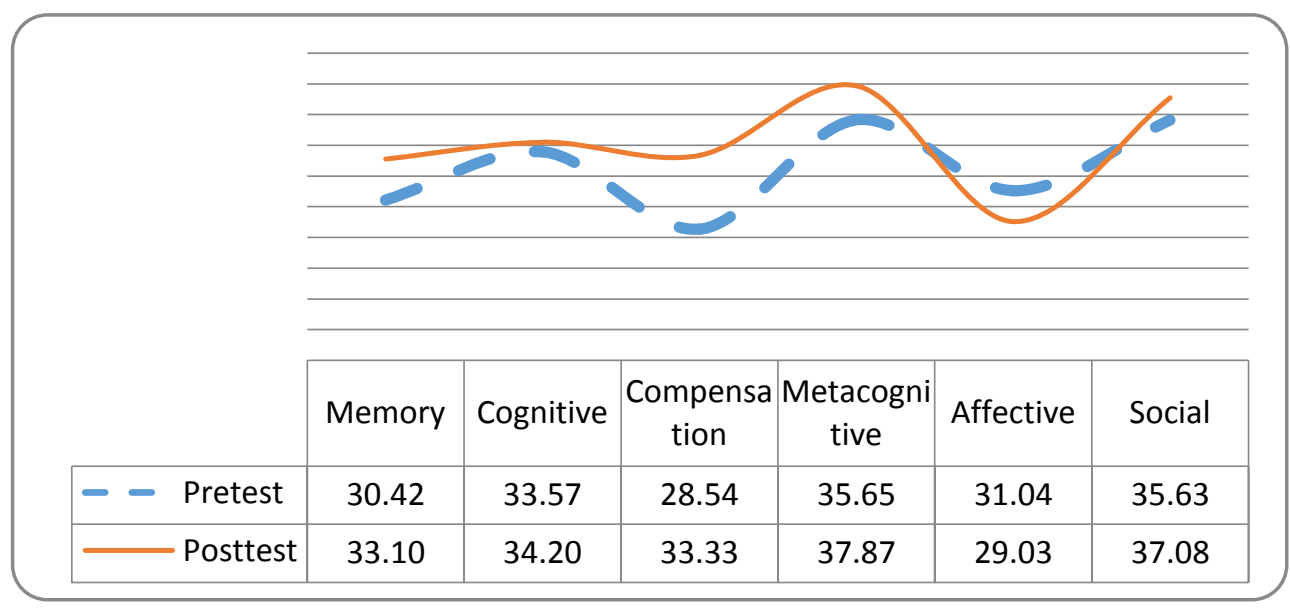

Graph 4. Components of Pretests and Posttests of LLS (Jigsaw Group)

Therefore, when language learning strategies are treated as a unitary construct regardless of the components, the task type (i.e jigsaw) does not affectlearners' frequency of strategy use. However, when the components of language learning strategies are scrutinized, some changes in the strategic behavior of learners are revealed. It is notable that metacognitive, social, and cognitive strategies were used the most frequently by the learners.

\subsubsection{Investigation of the third research Question}

The third research question, concerned with the effect of exposure to problem-solving tasks on the use of language learning strategies by Iranian EFL learners, was addressed twice probing the effect of problem-solving tasks on language learning strategies as a unitary construct first and then on its components.

\subsubsection{Language learning strategies as a unitary construct (problem-solving group)}

A paired-samples t-test was run to compare problem-solving group's means on pretest and posttest of total language learning strategies. As displayed in table 21, the problem-solving group showed almost the same means on the posttest of language learning strategies $(M=169.08, S E=3.66)$ than the pretest $(M=169.38, S D=5.59)$ on posttest of language learning strategies.

Table 21. Paired Samples Statistics

\begin{tabular}{lrc}
\hline \multicolumn{3}{c}{ Mean N Std. Deviation Std. Error Mean } \\
\hline Posttest 169.08 2618.687 & 3.665 \\
Pretest & 169.382628 .515 & 5.592 \\
\hline
\end{tabular}

The results of the paired-samples t-test $(\mathrm{t}(25)=.058, \mathrm{P}>.05, \mathrm{R}=.012$ representing a weak effect size) (table 22) indicated that there was not any significant difference between the problem-solving group's mean scores on pretests and posttest of language learning strategies. The null-hypothesiswas not rejected.

Table 22. Paired-samples T-test, Pretest and Posttest of LLS (Problem-solving group)

\begin{tabular}{|c|c|c|c|c|c|c|c|}
\hline \multicolumn{5}{|c|}{ Paired Differences } & \multirow[t]{3}{*}{$\mathrm{T}$} & \multirow[t]{3}{*}{$d f$} & \multirow[t]{3}{*}{ Sig. (2-tailed) } \\
\hline Mean & Std. Deviation & Std. Error Mean & $\begin{array}{l}95 \% \text { Cor } \\
\text { Differenc }\end{array}$ & Interval of the & & & \\
\hline & & & Lower & Upper & & & \\
\hline .308 & 27.258 & 5.346 & -10.702 & 11.318 & .058 & 25 & .955 \\
\hline
\end{tabular}




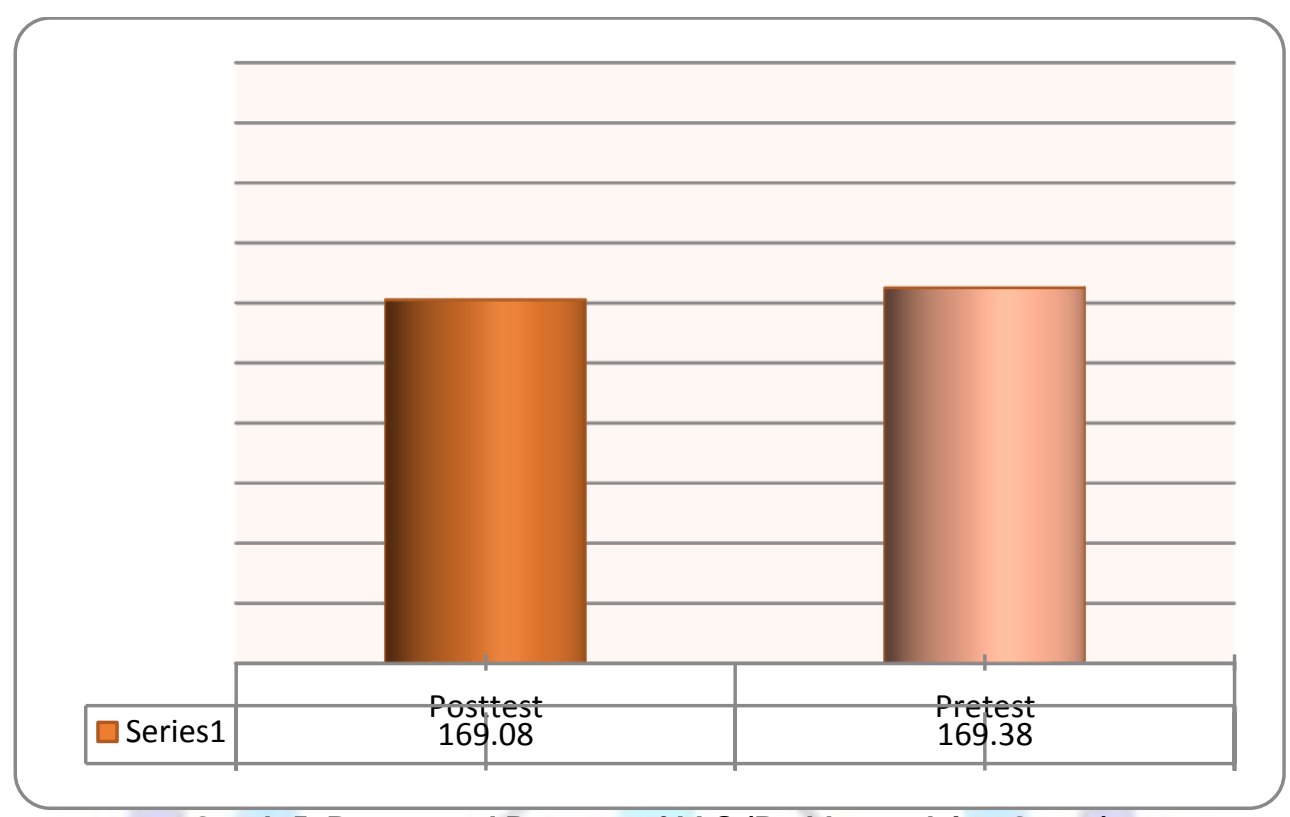

Graph 5. Pretest and Posttest of LLS (Problem-solving Group)

\subsubsection{Components of language learning strategies (problem-solving group)}

A repeated measures ANOVA was run to compare problem-solving group's means on pretest and posttest of component of Language Learning Strategies. Based on the results displayed in tables 23 and 24 it can be concluded that there was not any significant difference between the problem-solving group's overall means on pretest $(M=32.62)$ and posttest $(M=$ 33.80) $\left(F(1,25)=.030, P>.05\right.$, Partial $\eta^{2}=.001$ representing a weak effect size). Then, the null-hypothesis was not rejected.

Table 23.Multivariate Tests; Pretests and Posttests of Components of LLS (Problem-solving Group)

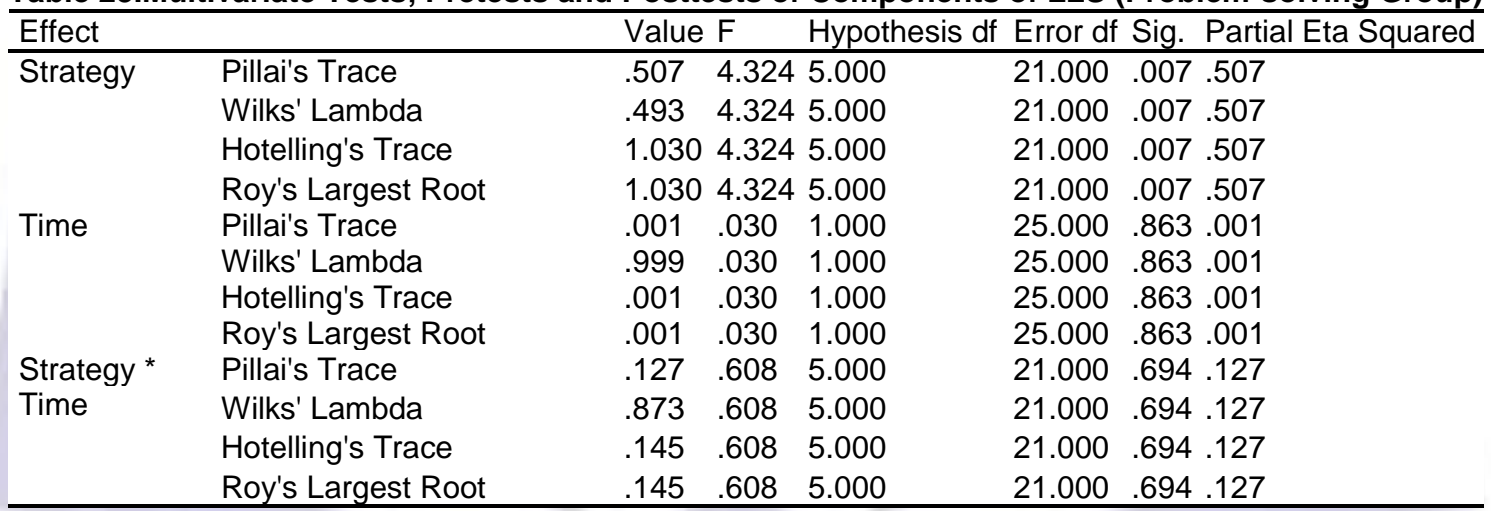

Table 24.Descriptive Statistics; Pretest and Posttest of LLS (Problem-solving Group)

\begin{tabular}{lllll}
\hline Time & Mean & Std. Error & \multicolumn{2}{l}{ 95\% Confidence Interval } \\
\cline { 4 - 5 } & & & Lower Bound & Upper Bound \\
\hline Pretest & 33.628 & 1.105 & 31.352 & 35.904 \\
Posttest & 33.807 & .703 & 32.359 & 35.256 \\
\hline
\end{tabular}

Based on the results displayed in tables 23-26, it can be concluded that there were significant differences between the problem-solving group's means on the components of LLS; disregarding the time variable $(F(5,21)=4.32, P<.05, P a r t i a l$ $\eta^{2}=.50$, representing a large effect size). As displayed in table 25, the problem-solving group showed the highest means on metacognitive strategies $(M=36.49)$, social strategies $(M=35.73)$ and cognitive strategies $(M=34.08)$. They showed almost the same means on memory strategies $(M=32.11)$, compensation strategies $(M=31.69)$ and affective strategies $(\mathrm{M}=32.17)$. 
Table 25. Descriptive Statistics; Components of LLS (Problem-solving Group)

\begin{tabular}{lllll}
\hline Strategy & Mean & Std. Error & \multicolumn{2}{c}{$95 \%$ Confidence Interval } \\
\cline { 4 - 5 } & & & Lower Bound & Upper Bound \\
\hline Memory & 32.115 & .847 & 30.371 & 33.859 \\
Cognitive & 34.080 & .944 & 32.135 & 36.024 \\
Compensation & 31.699 & .935 & 29.772 & 33.625 \\
Metacognitive & 36.496 & 1.165 & 34.096 & 38.896 \\
Affective & 32.179 & 1.073 & 29.969 & 34.390 \\
Social & 35.737 & 1.319 & 33.020 & 38.454 \\
\hline
\end{tabular}

Table 26 displays the results of the post-hoc comparison tests. Based on these results it can be concluded that there were significant differences between the following two means;
A: Metacognitive $(M=36.49)$ and Memory $(M=32.11)(M D=4.38, P<.05)$.
B: Metacognitive $(M=36.49)$ and Compensation $(M=31.69)(M D=4.79, P<.05)$.
C: Metacognitive $(M=36.49)$ and Cognitive $(M=34.08)(M D=2.41, P<.05)$.

Table 26.Post-Hoc Comparison Tests; Components of LLS (Problem-solving Group) $\begin{array}{lll}(\mathrm{I}) \text { Strategy } & \text { (J) Strategy Mean Difference (I-J) Std. Error Sig. } \\ & \end{array}$

\begin{tabular}{|c|c|c|c|c|}
\hline \multirow{3}{*}{ Memory } & Cognitive & -1.964 & 889 & 549 \\
\hline & Compensation & .417 & .849 & 1.000 \\
\hline & Metacognitive & $-4.380^{\circ}$ & .987 & .002 \\
\hline \multirow{5}{*}{ Cognitive } & Affective & -.064 & $\overline{1.074}$ & 1.000 \\
\hline & Social & -3.622 & 1.345 & .187 \\
\hline & Memory & 1.964 & .889 & .549 \\
\hline & Compensation & 2.381 & .908 & .221 \\
\hline & Metacognitive & $-2.416^{*}$ & .735 & .045 \\
\hline \multirow{5}{*}{ Compensation } & Affective & $\overline{1.900}$ & $\overline{1.273}$ & $\overline{1.000}$ \\
\hline & Social & -1.658 & .959 & 1.000 \\
\hline & Memory & -.417 & .849 & 1.000 \\
\hline & Cognitive & -2.381 & .908 & .221 \\
\hline & Metacognitive & $-4.797^{*}$ & 1.179 & .006 \\
\hline \multirow{5}{*}{ Metacognitive } & Affective & -.481 & $\overline{1.164}$ & $\overline{1.000}$ \\
\hline & Social & -4.038 & 1.297 & .069 \\
\hline & Memory & $\underline{4.380^{*}}$ & .987 & .002 \\
\hline & $\overline{\text { Cognitive }}$ & $2.416^{\star}$ & .735 & .045 \\
\hline & Compensation & $4.797^{\star}$ & $\overline{1.179}$ & .006 \\
\hline \multirow[b]{3}{*}{ Affective } & Affective & 4.316 & 1.414 & .080 \\
\hline & Social & .759 & 1.241 & 1.000 \\
\hline & Memory & .064 & 1.074 & 1.000 \\
\hline \multirow{9}{*}{ Social } & Cognitive & -1.900 & 1.273 & 1.000 \\
\hline & Compensation & .481 & 1.164 & 1.000 \\
\hline & Metacognitive & -4.316 & 1.414 & .080 \\
\hline & Social & -3.558 & 1.323 & .189 \\
\hline & Memory & 3.622 & 1.345 & .187 \\
\hline & Cognitive & 1.658 & .959 & 1.000 \\
\hline & Compensation & 4.038 & 1.297 & .069 \\
\hline & Metacognitive & -.759 & 1.241 & 1.000 \\
\hline & Affective & 3.558 & 1.323 & .189 \\
\hline
\end{tabular}

* The mean difference is significant at the .05 level. (Highlighted, underlined and italicized).

Note. Each comparison was reported twice. The negative sign means that the first mean was smaller.

Based on the results displayed in tables 23-28, it can be concluded that there was a non-significant but moderate to large interaction between time and Components of language learning strategies $\left(F(5,21)=.608, P>.05, P\right.$ artial $\eta^{2}=.12$ representing a moderate to large effect size). Bar graph 7 displays the problem-solving group's means on components of pretests and posttests of language learning strategies. 
Table 27.Descriptive Statistics; Time*Components (Problem-solving Group)

\begin{tabular}{llllll}
\hline Strategy & Time & Mean & Std. Error & \multicolumn{2}{c}{ 95\% Confidence Interval } \\
\cline { 3 - 6 } & & & & Lower Bound & Upper Bound \\
\hline Memory & Pretest & 32.222 & 1.118 & 29.920 & 34.525 \\
\multirow{2}{*}{ Cognitive } & Posttest & 32.009 & .961 & 30.030 & 33.987 \\
\multirow{2}{*}{ Compensation } & Pretest & 34.588 & 1.346 & 31.816 & 37.360 \\
& Posttest & 33.571 & 1.034 & 31.442 & 35.701 \\
Metacognitive & Pretest & 31.346 & 1.356 & 28.554 & 34.138 \\
\multirow{2}{*}{ Affective } & Posttest & 32.051 & .980 & 30.033 & 34.069 \\
& Posttest & 36.624 & 1.562 & 33.406 & 39.841 \\
Social & Pretest & 36.368 & 1.067 & 34.171 & 38.565 \\
& Posttest & 32.949 & 1.323 & 28.686 & 34.134 \\
& Pretest & 35.577 & 1.809 & 30.493 & 35.404 \\
\hline & Posttest & 35.897 & 1.337 & 33.851 & 39.303 \\
& & & & & 38.652 \\
\hline
\end{tabular}

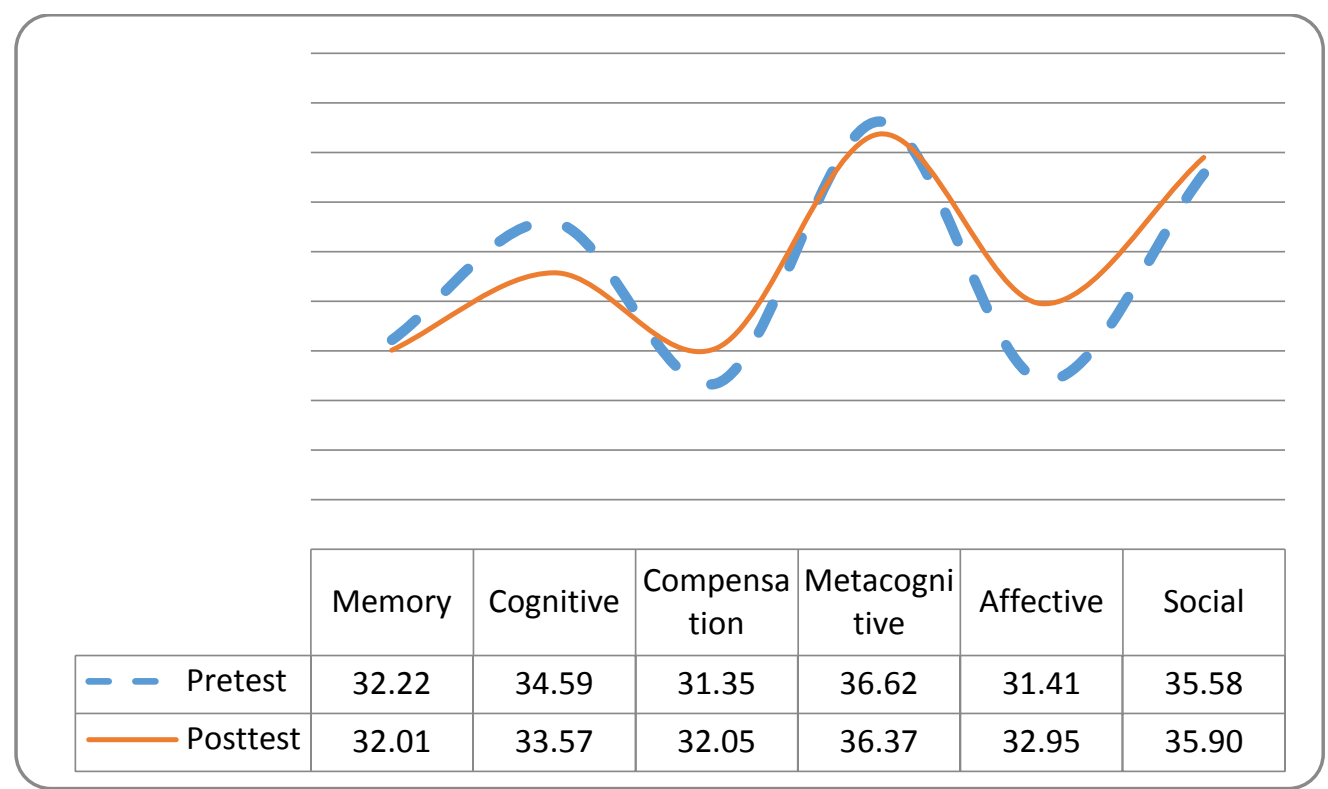

Graph 6. Components of Pretests and Posttests of LLS (Problem-solving Group)

Thus, regarding language learning strategies as a unitary construct, exposure to problem-solving tasks does not affect learners' strategy use (i.e. the total number of strategies used is not changed). Nevertheless, when the components of language learning strategies are examined, it is indicated that the task type affects learners' use of different strategy types. The highest means belongs to metacognitive, social, and cognitive strategies.

\section{Discussion and Conclusion}

Approaching the LLSs as a unitary entity, the findings showed that the two groups were not significantly different indicating that the task types do not much influence the overall strategy use. This is in line with Oxford et al.'s (2004) study in which total reported mean frequency of strategy use did not differ significantly across three task conditions. The same result was reached by Sotudenama and Azimfar (2012) as well as Fazilatfar (2010).However, this result is inconsistent with findings of the study done by Khan (2010) who concluded that overall strategy use varies across different task types. It is also inconsistent with Junsheng's (2008) and Kaivanpanah, Yamouty, and Karami's (2012) findings. This was also partially true with respect to thecomponentsof LLSs. The only significant difference between the two groups was in affective strategies. This is in line with Khan's (2010) study which found that only a few strategies differed across task types. Moreover, the participants in the jigsaw group favored metacognitive, social, and cognitive strategies. This is in line with Junsheng's (2010) study in which learners employed cognitive and metacognitive strategies to do actual classroom tasks. Learners' infrequent use of compensatory strategies is inconsistent with Smith's (2003) research in which participants reported use of this strategy type in doing a jigsaw task. However, the analysis done on the subcategories of learning strategies showed that the students' strategic behavior changed after exposure to problem-solving tasks. It isnotable that metacognitive, social, and cognitive strategies were most frequently used by the learners. Results indicated that both groups were similar in terms of the strategy types they used more frequently as also Smith (2003) reports in his study in which similar pattern of strategy use across different task types was reported. 
It then may be safely concluded that, statistically speaking, task type does not play a significant role in LLS selection and use either as a unitary construct or when addressed componetially. However, componetially certain components appeared to have different pictures or realizations. This status quo may be attributed to the fact that in a jigsaw task a lot of negotiations happen which require the use of social strategies. The students may need to ask others for clarification, repetition, and other sorts of help. With regard to cognitive strategies, the students may have used skimming, scanning, and summarizing the information in the text in order to transfer the necessary information to other group members. As to the effects of problem solving tasks to LLS selection, metacognitive, social, and cognitive strategies were most frequently used. On the other hand, the problem-solving group outperformed on the posttest. This is justified on the nature of the task and the exposure of the members to more consciousness -raising statements in the questionnaire in the pretest stage.Generally, the insignificant results may imply that the target tasks are rested in the same psychological and underlying constructs in spite of their assumed format and structural differences. Perhaps if strategic behavior of learners is compared in doing non-communicative tasks with communicative ones more differences will be observed.

\section{REFERENCES}

[1] Bacon, S. (1992). The relationship between gender, comprehension, processing strategies, and cognitive and affective responses in foreign language listening. The Modern Language Journal, 76, 160-177.

[2] Beglar, D., and Hunt, A. (2002). Implementing task-based language teaching. In J. Richards, \& W. Renandya, Methodology in task-based teaching: An analogy of current practice (pp. 96-109). Cambridge: Cambridge University

Press.

[3] Cohen, A., and Macaro, E. (2007). Language learner strategies. Oxford: Oxford University Press.

[4] Doughty, C., and Pica, T. (1986). Information-gap tasks: Do they facilitate second language acquisition? TESOL Quarterly, 20 (2), 305-325.

[5] Dreyer, C., and Oxford, R. (1996). Learning strategies and other predictors of ESL proficiency among Afrikaansspeakers in South Africa. In R. Oxford, Language learning strategies around the wrold: Cross cultural perspectives (pp. 61-74). Manoa: University of Hawaii Publishers.

[6] Ehrman, M., and Oxford, R. (1988). Effects of sex differences, career choice,and psychological type on adult language learning strategies. The Modern Language Journal, 72 (iii), 253-265.

[7] Ellis, R. (2003). Task-based language learning and teaching. Oxford: Oxford University Press.

[8] Fazilatfar, A. (2010). A study of reading strategies using task-based strategy assessment. Journal of English language learning and teaching, 53 (217), 19-44.

[9] Fredricks, C. (1984). Types of oral communication activities and the language they generate. System, 12 (2), $133-146$.

[10] Hong-Nam, K., and Leavell, A. (2006). Language learning strategies of ESL students in an intensive English language context. System, 34, 399-415.

[11] Hsiao, T., and Oxford, R. (2002). Comparing theories of language learning strategies: A confirmatory factor analysis. The modern Language Journal, 2, 368-383.

[12] Hussein, H., Roslan, S., Noordin, N., and Abdullah, M. (2012). Using the problem-solving approach to teach writing to EFL learners. The English Teacher, XLI (2), 144-159.

[13] Jnnsheng, H. (2008). Interactive integration: English language learning strategies, styles, and tasks in a school in Fujian (Unpublished doctoral dissertation). University of Hong Kong, Pokfulam, Hong Kong. 


\section{ISSN 2321-1091}

[14] Kaivanpanah, S., Yamouty, P., and Karami, H. (2012). Examining the effects of proficiency, gender, and task type on the use of communication strategies. Porta Linguarum, 17, 79-93.

[15] Kazemi, M. (2012). The effect of jigsaw technique on learners' reading achievement: The case of English as L2. MJAL, 4 (3), 171-184.

[16] Khan, S. (2010). Strategies and spoken production on three oral communication tasks (Unpublished doctoral dissertation). The Autonomous University of Barcelona, Barcelona, Spain.

[17] Mitchell, R., and Myles, F. (1998). Second language learning theories. London: Arnold Publishers.

[18] Mengduo, Q., and Xiaoling, J. (2010). Jigsaw as a coperative learning technique: Focusing on the learners. Chinese Journal of Applied Linguistics, 33 (4), 113-125.

[19] Naiman, N. (1978). The good language learner. Toronto: Ontario Institute for Studies in Education.

[20] Nunan, D. (1998). Second language teaching and learning. Boston: Heinle\& Heinle Publishers.

[21] O'Malley, J.\&Chamot, A. (1990). Learning strategies in second language acquisition. Cambridge:Cambridge University Press.

[22] Oxford, R. (1989). Use of language learning strategies: A synthesis of studies with implications for strategy training. System, 17 (2), 235-242.

[23] Oxford, R., and Nyikos, M. (1989). Variables affecting the choice of language learning strategies by university students. The Modern Language Journal, 73, 291-300.

[24] Oxford, R. (1990). Language learning strategies: What every teacher should know. Boston: Heinle\&Heinle.

[25] Oxford, R., and Ehrman, M. (1995). Adults' learning strategies in an intensive foreign language program in the United States. System, 23 (3), 359-386.

[26] Oxford, R. (1999). Relationship between second language learning strategies and language proficiency in the context of learner autonomy and self-regulation. Revista Canaria de Estudios Ingleses, 38, 109-126.

[27] Oxford, R., Cho, Y., Leung, S., and Kim, H. (2004). Effect of presence and difficulty of task on strategy use: An exploratory study. International Review of Applied Linguistics, 42, 1-47.

[26] Poupore, G. (2005). Quality interaction and type of negotiation in problem-solving and jigsaw tasks. In C. E. Willis, Teachers exploring tasks in English language teaching (pp. 242-255). New York: Palgrave Macmillian.

[27] Prabhu, N. (1987). Second language pedagogy. Oxford: Oxford University Press.

[28] Richards, J. (2001). Curriculum development in language teaching. Cambridge: Cambridge University Press.

[29] Rubin, J. (1975). What the good language learner can teach us. TESOL Quarterly, 9 (1), 41-51.

[30] Smith, B. (2003). The use of communication strategies in computer-mediated communication. System, 31, 29-53.

[31] Sotudenama, E., and Azimfar, F. (2011). The effect of presence versus absence of reading task and its difficulty level on reading strategy use. Portal Liguarum, 16, 105-121.

[32] Stern, H. (1975). What can we learn from the good language learner. The Canadian Modern Language Review, 31 , 304-318. 


\section{ISSN 2321-1091}

[33] Swain, M., and Lapkin, S. (2000). Focus on form through collaborative dialogue: Exploring task effects. In M. Bygate,

P. Skehan, \& M. Swain, Researching pedagogical tasks, second language learning, teaching, and testing (pp. 99-

118). Harlow: Adison Wesly Longman.

[34] Taguchi, T. (2002). Learner factors affecting the use of learning strategies in ceoss-cultural contexts. Prospect, 17 (2), 18-32.

[35] Willis.J. (1996). A framework for task-based language learning. Harlow: Addison Wesly Longman.

[36] Wilis, D., and Willis, J. (2007). Doing task-based teaching. Oxford: Oxford University Press.

[37] Ziahosseini, M., and Salehi, M. (2008). An investigation of the relationship between motivation and language learning strategies. Pazhuhesh-e Zabanha-ye Khareji, 41, 85-107.

\section{Authors' biographies with photos}

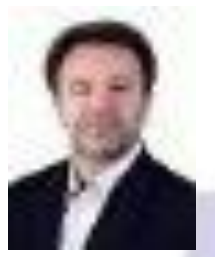

Dr. Gholam-Reza Abbasian, an assistant professor of TEFL at Imam Ali University and IAU (South Tehran Branch), has presented (inter) national conferences, authored and translated about 15 books, and published a good number of scholarly articles. He offers mainly Psycholinguistics, Language Testing, and Syllabus Design courses. He has received awards as top scholar and the most successful teacher for almost seven consecutive years. He is the internal manager of JOMM, reviewer of FLA and GJER journals and a member of the editorial board of JSSIR.

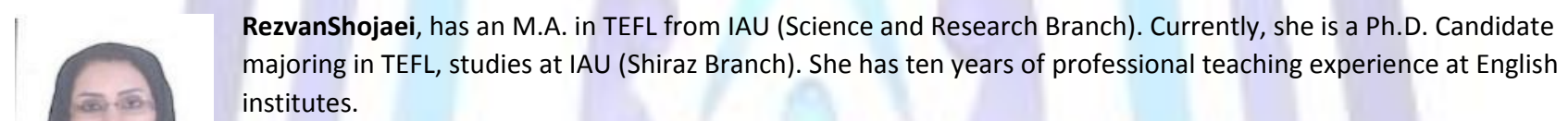

RezvanShojaei, has an M.A. in TEFL from IAU (Science and Research Branch). Currently, she is a Ph.D. Candidate
majoring in TEFL, studies at IAU (Shiraz Branch). She has ten years of professional teaching experience at English institutes. 